\title{
Training of trainers: An action-based research for improving the pedagogical skills of academicians
}

\author{
Bayram Özer', Volkan Duran², Mustafa Tekke \\ ${ }^{1}$ Department of Curriculum and Instruction, Ondokuz Mayıs University, Turkey \\ ${ }^{2}$ Psychology Department, Iğdır University, Turkey \\ ${ }^{3}$ Psychological Guidance and Counseling Department, Düzce University, Turkey
}

\begin{tabular}{l}
\hline Article Info \\
\hline Article history: \\
Received Sep 13, 2019 \\
Revised May 25, 2020 \\
Accepted Jul 15, 2020 \\
\hline
\end{tabular}

\section{Keywords:}

Academicians

Education in universities

Pedagogical skills

Training of trainers

\begin{abstract}
Based on the philosophy of lifelong education, private/public institutions and organizations invest in continuous training of human resources. Universities also organize in-service trainings regarding the general principles of teaching and learning in the context lifelong learning activities for the development of the pedagogical skills of the academicians who have difficulty in using teaching skills and principles in the courses in their universities. Therefore, a Project entitled as Training of Trainers based on action research based on qualitative research design was carried out for aiming at providing pedagogical education for the academicians who work in different departments of Ondokuz Mayis University who are experts in different disciplines but who do not have pedagogical background in order to gain experience in basic skills and principles in education area so as to improve the quality of education in this way. During the project, which lasted for a total of 2 years, 246 academicians were trained in 24 different subjects, the opinions of the participants were taken and the distribution of these views was reflected in the tables in text. Finally, the asymptotic Significance (2-sided) for Pearson Chi-Square indicates of the yes/no answer indicates that there is a dramatic change regarding the effectiveness of the program. It is seen that it meets the needs of academicians. Therefore, the program based on action research design shows that such in-service pedagogical programs could be useful for higher education in this respect.
\end{abstract}

This is an open access article under the CC BY-SA license.

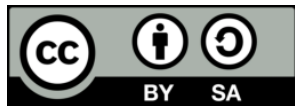

\section{Corresponding Author:}

Bayram Özer,

Department of Curriculum and Instruction,

Ondokuz Mayıs University,

Kurupelit Campus, Samsun, Turkey.

Email: ozer.bayram@gmail.com

\section{INTRODUCTION}

As a requirement of the philosophy of lifelong education, individuals and institutions must constantly strive for learning in order to stand out and make a difference. Continuous learning of natural capital is even more essential, given that professions are updated every four years on median. To achieve this, private/public institutions and organisations are investing in ongoing human resources formation. The rapidly evolving requirements of this decade make universities as the top of these institutions. Education and training operations are one of the major tasks of universities. Taking into account the features of the target audience, teaching in higher education has distinct features and dynamics than teaching in primary or secondary education. The target group in higher education is accepted as an adult and can not succeed unless it willingly 
joins. Therefore, it is necessary to use different practices and methods than the rules and methods used for the education of children.

Teaching is also a profession distincting itself other disciplines by its own knowledge types. In this regard, there are three different kinds of knowledge in any teaching profession that can be used instructurs. These are the content knowledge, general knowledge of instructional methods (pedagogical knowledge), pedagogical content knowledge. Especially pedagogical knowledge is a knowledge type that distiguishes teaching profession from the other disciplines. Knowledge of Pedagogical Content (PCK) reflects a comprehensive educational concept. It is based on the conviction that teaching involves significantly greater understanding than providing learners with topic-specific knowledge and that learning is far more so than acquiring data for subsequent regeneration [1]. The understanding of the pedagogical content knowledge is a kind of understanding distinctive to educators, depending on how educators connect their pedagogical knowledge (what they think about learning) to their understanding of the content (what they think about what they practice) [2]. According to Shulman [3] pedagogical content knowledge:

...embodies the aspects of content most germane to its teachability. Within the category of pedagogical content knowledge I include, for the most regularly taught topics in one's subject area, the most useful forms of representation of those ideas, the most powerful analogies, illustrations, examples, explanations, and demonstrations - in a word, the ways of representing and formulating the subject that make it comprehensible to others ... [It] also includes an understanding of what makes the learning of specific concepts easy or difficult: the conceptions and preconceptions that students of different ages and backgrounds bring with them to the learning.

A year later, Shulman extended the theoretical framework of the teacher knowledge base into seven categories: (a) content knowledge, (b) general pedagogical knowledge, (c) curriculum knowledge, (d) pedagogical content knowledge, (e) knowledge of learners and their characteristics, (f) knowledge of the educational contexts as environment and conditions; and (g) knowledge of educational ends, purposes, and values and their philosophical and historical grounds [4].

Content knowledge covers the teacher's knowledge about the structure of the field as well as the concepts and facts in the field. Content knowledge includes the methods used to determine the accuracy or inaccuracy, validity or invalidity of the concepts and facts in the field and the ways used in the production and structuring of information in the field. General pedagogical knowledge is about how the teacher can teach. Variables such as student recognition, learning theories, principles and strategies in classroom management, material development and use, measurement and assessment knowledge and skills are included in this category. Curriculum knowledge is the knowledge of when and how to use resources (textbooks, concrete materials, software, technological tools) related to the curriculum in a learning area. Pedagogical content knowledge is the category where content and pedagogical knowledge intersect and serve as a complementary bridge between these two. Knowledge about students and their characteristics includes the physical, mental, social, emotional, linguistic and psychological developmental stages, the functioning of their mental and social structures, their interests and needs, and how they can learn better can be regarded within the scope of this knowledge type. Knowledge of educational environment and conditions (context information) is related to the opportunities, expectations and limitations of the region where the teacher works, the school environment and the knowledge of the students' families, interests and backgrounds. Knowledge of educational ends, purposes includes the aims, objectives and values of education, the philosophical, historical foundations and general aims of education $[5,6]$.

Shulman's work [3, 4] has re-underlined the importance of field knowledge at a time when teaching was only examined from a general pedagogical point of view, and field knowledge was considered only a detail [7]. Therefore, pedagogical knowledge as well as other knowledge types for education has significance for any given field related with the education. Therefore it is a must for anyone in any profession to acquire those skills in order to teach more effectively. Therefore, the National Education Ministry (1946, 1982) stressed the significance of pedagogical formation of the faculty members and also the need for training them. This problem has been highlighted at the global stage, and universities are organizing their programmes accordingly. In particular, studies by medical faculties are especially prominsent in this area $[8,9]$. The duties of institutions for higher education are not restricted solely by research and instruction. The development of educational possibilities and the education of skilled learners make the universities more precious. Here, the teacher's standard of pedagogy is an significant element in creating a suitable learning atmosphere. MEB [10] also prepared the educational qualifications list for this as; personal and professional values - professional development, recognition of the student, learning and 
teaching process, monitoring and evaluation of learning-development, school-family and community relations, program and content knowledge.

These skills considered the instruction to be a profession and thus enhanced its significance and efficiency. These criteria were also determinant factors in the exams for teacher training institutions and teacher appointment. Not only the teacher-training institutions, but all the other institutions took the path to enhance their trainers ' equipment by taking into account this criteria. In this connection, universities are among the largest organizations. However, universities are seen to continue to be inadequate for pedagogical developments in terms of structural changes. For example, the findings implying that successful students in Turkey had less interest in becoming a faculty member or academicias have clearly shown that higher education lacks the required and the desired quality of education [10]. In this respect, YÖK has accredited universities in terms of academic organisations, number of students, programs and other procedures. The assessments produced by the students in particular stand out in the assessment of the staff representative altough it is doubtful that these assessments are objective. In particular, requirements such as efficient teacher introduction, mastery, communication with the students and interaction with the community are included in the scope of the assessment. Such feedback is nevertheless essential for teachers to understand that someone else can see their ability [11]. It is also as a plus for staff employees to retain and grow in view of their faults and abilities for a fresh instructional phase.

\section{Development of academicians in Turkey in terms of their pedagogical skills}

Academicians in Turkey have no sufficient pedagogical format to enhance their teaching skills. Therefore, the classes given to undergraduate learners in the university are insufficient with regard to pedagogy, with the exception of those working in education faculties. In 2000, YÖK (council of higher education in Turkey) made pedagogical formation compulsory in master's and doctorate programs. However, these courses were no longer compulsory and and academics began to take courses as academicians without any training to improve their teaching skills during their graduate, doctoratal education periods.

Although this is the case throughout the country in 1996, Dokuz Eylül University [12] and then Istanbul University in 1997 [13], Hacettepe University in 1998, Ankara University in 1999 [14], Marmara University [11] and Ege University [15] short-term programs called training of trainers have been carried out. However, an important problem observed in these programs, especially those related to medical education is that the trainers don't have pedagogical background. Altough these trainings given to the academicians by academicians who are assigned from the same institution having academic studies in the field of medical education but do not have any training related to the educational formation they are important because they are pioneering studies on the subject.

\section{Content of trainer's training program}

Many roles and tasks are expected from teachers. These roles are important in the past as they are important in the past and it is thought that they will not lose their importance in the future. For example, although the roles of teachers has been understood in the past as people who convey information, in other words, to instruct directly students, it is no longer sufficient today to teach, instead it needs to be guided, to predict future results about decisions, engage in social processes and participate in efforts to protect natüre. Trainer training programs must be drawn up having into consideration the learning abilities and pedagogical abilities of the experts conducting these educations. The contents should also be scheduled and carried out according to the teacher's skills. Teaching qualifications are determined and published by the Ministry of National Education and appear to be in six main titles. Each trainer should essentially have these skills. These abilities are demonstrated in the practice of trainers for this intent. This is recognized immediately as the primary criterion for determining the performance of the school's learners. Effective teachers will directly affect the success of the student [16-21].

Investigations suggest that teachers and academics are not sufficiently sensitive to the growth of their pedagogical backgrounds, particularly in educational faculties, and in universities. These studies [14, 22-25] address these problems; that faculty members do not give enough importance to this issue, they believe that their education abilities are immediately linked to the growth of their understanding of material and content knowledge; they live an isolated life style, over-specialization in a particular subject prevents academics from improving themselves in education, and that research on educational development is limited and national education and health policies have a negative impact. Therefore, the aim of this study is to evaluate the educator skills of university educators in our country by using qualitative research method in a wide scope. Therefore, content of the program was arranged aiming mostly at general pedagogical knowledge of the academicians. For example, in one activity, detailed prescription for frying eggs were given and they were expected to cook it based on this instruction. Similarly various topics like adult education, assesment and evaluation methods were given in the program. 


\section{RESEARCH METHOD}

In order to improve expertise regarding the fundamental pedagógical abilities and to enhance pedagogical communication among academics, this study has been designed to take into account the views of academicians before and after the programme. In this sense the training program carried out by Ondokuz Mayis University for the development of teaching skills and training for academics covering all academic units in the university could be regarded as the first and the most comprehensive training program in Turkey. When the content of the training is evaluated in terms of the qualifications of the trainers, the duration of the training and the participants, the development of instructional skills for academicians is different from the other projects. They are expected to meet multidisciplinary academic vision by meeting with faculty members from different fields.

This study is based on action research design. Action research is defined as a systematic intervention process that takes place on the basis of people doing research about their professional actions and taking action for change. Action Research includes identifying issues immediately linked with the method of implemantation or collecting and analyzing systemic information for understanding and resolving these issues by the involvement of the participants such as classroom executives, educators and educational experts within the case or problematic situation. In addition, action researchers concentrate on obtaining information that enables them to change the circumstances of a particular situation, rather than looking for sound generalizations [26-29].

For this purpose, the advancement of the training of academician in terms of pedagogical development is regarded as a main concern for this research. Therefore, researchers developed a pedagogical formation program based on action research design where the participants are expected to reach the following objectives as given:

a. Preparing a teaching plan, based on modern teaching techniques in accordance with their fields of expertise as well as learning the skills of teachin, learning methods and effective presentation skills,

b. To be able to act in accordance with the learning principles adult education in educational activities,

c. To be able to determine the training needs of the participants in a training program and to create an appropriate training program,

d. Creating and maintaining a positive educational environment,

e. Facilitate training by applying the rules of communication,

f. Selecting and applying the method according to the purpose of the training,

g. Properly prepare and use the tools and equipment that facilitate education,

h. Prepare and make an effective presentation,

i. Develop and implement tools to evaluate the educational process and outcome

In addition, faculty members participating in the training can learn

a. To prepare an efficient training plan,

b. To create a learning environment suitable for the subject and the student for an efficient course,

c. To choose the appropriate learning method for the subject and the student for an efficient course,

d. To conduct learning activities for an efficient course,

e. To choose the most appropriate assessment method for the assessment of the course and skills,

f. To learn educational instrument development, applications and scoring in accordance with the assessment method,

g. To develop measures to accelerate education and learning,

h. To comprehend the ways to increase productivity in education and to learn the learning processes,

i. To have sufficient knowledge and skills to develop themselves as trainers

\subsection{Population}

Training was held at Samsun Ondokuz May1s University between 2014 and 2016 for the development of educational skills and formation for academicians covering all academic units within the university. Table 1 shows the distribution of 50 academicians among 246 academicians who participated in the training. 
Table 1. Distribution of academics participating in the project

\begin{tabular}{|c|c|c|c|c|}
\hline Order & Faculty & Date & $\begin{array}{l}\text { Participant } \\
\text { Number }\end{array}$ & $\begin{array}{l}\text { Study } \\
\text { Group }\end{array}$ \\
\hline 1 & Faculty of Aeronautics and Astronautics & 08 - 12 September 2014 & 14 & 4 \\
\hline 2 & Faculty of Civil Aviation & 08 - 12 September 2014 & 6 & 1 \\
\hline 3 & Engineering Faculty & 08 - 12 September 2014 & 10 & 3 \\
\hline 4 & Faculty of Education & 01 - 05 January 2015 & 5 & 1 \\
\hline 5 & Faculty of Arts and Sciences & 01 - 05 January 2015 & 5 & 1 \\
\hline 6 & Faculty of Economics and Administrative Sciences & 01 - 05 January 2015 & 5 & 1 \\
\hline 7 & Faculty of Theology & 01 - 05 January 2015 & 5 & 1 \\
\hline 8 & Faculty of Education & 07 - 12 January 2015 & 5 & 1 \\
\hline 9 & Faculty of Arts and Sciences & 07 - 12 January 2015 & 5 & 1 \\
\hline 10 & Faculty of Economics and Administrative Sciences & 07 - 12 January 2015 & 5 & 1 \\
\hline 11 & Faculty of Theology & 07 - 12 January 2015 & 5 & 1 \\
\hline 12 & Faculty of veterinary medicine & 23 - 27 February 2015 & 25 & 5 \\
\hline 13 & faculty of Agriculture & 01 - 05 June 2015 & 31 & 6 \\
\hline 14 & Faculty of Dentistry & 08 - 12 June 2015 & 25 & 5 \\
\hline 15 & Vocational School of Health Services & 14 - 18 September 2015 & 5 & 1 \\
\hline 16 & Samsun School of Health & 14 - 18 September 2015 & 33 & 6 \\
\hline 17 & Yaşar Doğu Faculty of Sport Sciences & 1 - 5 February 2016 & 6 & 1 \\
\hline 18 & Tourism Faculty & 1 - 5 February 2016 & 5 & 1 \\
\hline 19 & Communication faculty & 1 - 5 February 2016 & 11 & 2 \\
\hline 20 & Faculty of Dentistry & 1 - 5 February 2016 & 10 & 2 \\
\hline 21 & Ali Fuat Başgil Faculty of Law & 1 - 5 February 2016 & 15 & 3 \\
\hline \multirow[t]{2}{*}{22} & Faculty of Aeronautics and Astronautics & $11-15$ April 2016 & 10 & 2 \\
\hline & Total & & 246 & 50 \\
\hline
\end{tabular}

\subsection{Data collection}

All participants are academicians. A total of six open-ended questions were asked by asking four questions before the training and two after the training (see Table 2 to Table 6). The explanations obtained were recorded in writing on a regular basis. Participants volunteered in this study. The following is a list of questions asked before training.

a. What do you expect from the training?

b. As an academician, do you think you are inadequate in terms of pedagogical knowledge? If so, what are these?

c. Did you come to the training as a volunteer? Why?

d. Would you attend the training without the assignment?

e. Do you think this kind of training is necessary for academicians?

Following is the list of questions asked after the training.

a. What did you learn on the course?

b. Did you volunteer for the course?

c. Do you think the course is necessary?

d. Do you think academics need a course with this content?

e. Would you have attended the course if there was no assignment?

\subsection{Data analysis}

Because this study is a qualitative study, the content analysis method was used to evaluate the collected data. This analysis includes verbal or written data analysis [30]. Shulman (1987)'s seven categories [3, 4] for knowledge types were used in this regard. In doing this, the theme and frequency approach was used. An opinion of a participant was evaluated as a frequency and the frequencies were determined accordingly. Some of the participants gave more than one opinion and some of them did not give any opinion. Therefore, the total frequencies do not correspond to the total number of participants. The researchers agreed on the common theme by reading the collected data separately. It has been deemed appropriate to be in the form of main theme and sub theme.

\section{RESULTS AND DISCUSSION}

\subsection{Results}

The five questions asked in this section are the questions asked before the training. The content of the questions is to determine the expectations and thoughts of academicians from education. Expectations of academicians from education varied (Table 2). It is understood that most of them want to benefit from program through "teaching methods and techniques". The most important reason for this is that academicians 
still do not feel comfortable in the classroom education. For example, as it can be understood that the higher frequency regarding "learning more efficient methods in lecturing and sharing information with students" implies their feeling of inadequacy in terms of "teaching methods and techniques". The second higher frequency is about the item as "to determine the validity and reliability of our measurement and evaluation methods". On the other hand, it is understood that a small number of academicians have negative perceptions on education.

In Table 2, "Teaching Methods and Techniques" are seen as the most inadequate skill among the academicians. This is followed by "assesment and evaluation" (7), communication (5), seeing the missing points (5), other (5), self-improvement (3), learning new things (3). As it can be seen most of the remarks of the academicians are related to general pedagogical knowledge (28). It is followed by "knowledge of learners and their characteristics" (3) and self-improvement (3). Negative remarks also exists hence a small number of academics consider themselves sufficient in terms of general pedagogical knowledge. Therefore it can be seen that expectations of the academicians from this program is related to general pedagogical knowledge and knowledge of learners and their characteristics.

Table 2. Expectation of the academicians from the program

\begin{tabular}{|c|c|c|c|c|}
\hline Main Theme & Sub-theme & Code & $\mathrm{f}$ & Opinions \\
\hline \multirow{7}{*}{ Positive } & $\begin{array}{l}\text { General } \\
\text { pedagogical } \\
\text { knowledge }\end{array}$ & $\begin{array}{l}\text { Assesment and } \\
\text { Evaluation }\end{array}$ & 7 & $\begin{array}{l}\text { "to determine the validity and reliability of our measurement and } \\
\text { evaluation methods", "to learn the technique of exam } \\
\text { preparation", "to learn how to evaluate the learning outcomes } \\
\text { after class" }\end{array}$ \\
\hline & $\begin{array}{l}\text { General } \\
\text { pedagogical } \\
\text { knowledge }\end{array}$ & $\begin{array}{l}\text { Teaching Methods } \\
\text { and Techniques }\end{array}$ & 11 & $\begin{array}{l}\text { "learning more efficient methods in lecturing and sharing } \\
\text { information with students", "Gaining the ability to attract the } \\
\text { attention of the while teaching the course and gaining the ability } \\
\text { to explain the course in the most effective way" and "to learn } \\
\text { presentation techniques" }\end{array}$ \\
\hline & $\begin{array}{l}\text { Knowledge of } \\
\text { learners and their } \\
\text { characteristics }\end{array}$ & Self-improvement & 3 & $\begin{array}{l}\text { "Develop myself and become a better educator" ve "Both for my } \\
\text { personal development and for my student education, I should } \\
\text { attain new experiences that make my life easier" }\end{array}$ \\
\hline & $\begin{array}{l}\text { General } \\
\text { pedagogical } \\
\text { knowledge }\end{array}$ & Communication & 5 & $\begin{array}{l}\text { "Better communication with students" and "To learn how the } \\
\text { relationship between the student and the instructor should be in } \\
\text { the classroom" }\end{array}$ \\
\hline & $\begin{array}{l}\text { Self- } \\
\text { improvement }\end{array}$ & $\begin{array}{l}\text { Learning New } \\
\text { Things }\end{array}$ & 3 & $\begin{array}{l}\text { "Learning something new" ve "I want to hear and learn new } \\
\text { things" }\end{array}$ \\
\hline & $\begin{array}{l}\text { General } \\
\text { pedagogical } \\
\text { knowledge }\end{array}$ & $\begin{array}{l}\text { Seeing the } \\
\text { missing points }\end{array}$ & 5 & $\begin{array}{l}\text { "To reinforce what I know and complete what I don't know with } \\
\text { this training", "To see what we have been missing for many } \\
\text { years as an educator" ve "I want to know the wrong practices } \\
\text { that belongs to me". }\end{array}$ \\
\hline & & Other & 5 & $\begin{array}{l}\text { "To raise the bar of our quality of education and to add value to } \\
\text { us", "At the end of this one-week training, I believe that it is } \\
\text { really beneficial for me." and "Learning the beneficiary tricks to } \\
\text { be considered in the education process" }\end{array}$ \\
\hline Negative & $\begin{array}{l}\text { General } \\
\text { pedagogical } \\
\text { knowledge }\end{array}$ & & 8 & $\begin{array}{l}\text { "As someone with more than } 30 \text { years of experience, I don't } \\
\text { think it will add much", "I'm not hopeful", "I don't think it will } \\
\text { help", "I have been doing this for many years. I don't think it } \\
\text { will contribute much to me" }\end{array}$ \\
\hline
\end{tabular}

In Table 3, "Teaching Methods and Techniques" are seen as the most inadequate skill among the academicians. This is followed by "Communication", "Classroom and Time Management", "Unawareness" (5) are the second order inadequate skill among the academicians. "Professional Competency" is the fourth one (4) and the less felt inadequate skill is "Assesment and Evaluation" in this regard. Most of the remarks are related to general pedagogical knowledge $(n=12)$, second one is related to knowledge of educational contexts $(n=5)$ and the final one is related to content knowledge $(n=4)$. Negative remarks also exists hence a small number of academics consider themselves sufficient in terms of their educational adequecy.

The questions asked in Table 4 shows the perceptions of academics regarding their willingness for participation in the program. As it can be seen that most of them have positive attitudes toward the program $(n=20)$. Comparingly small number of them have negative attitude toward the program $(N=8)$. Similarly most of them indicate that such a formation program is necessary for improving themselves $(n=23)$ whereas small number of them disagree $(n=2)$. 
Table 3. Areas where academicians think that they think that they are insufficient

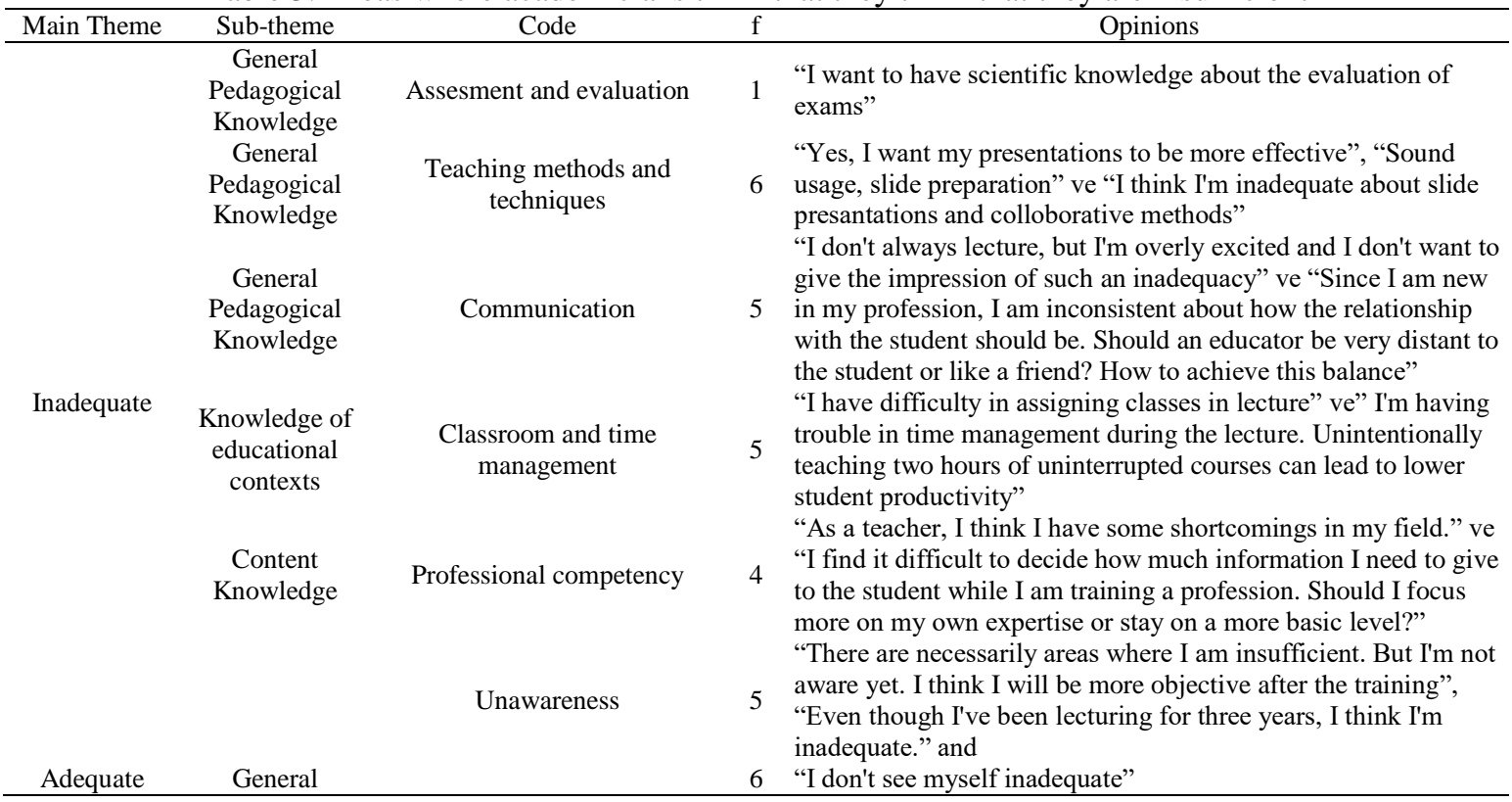

Table 4. Reasons and thoughts of academicians to participate in the program

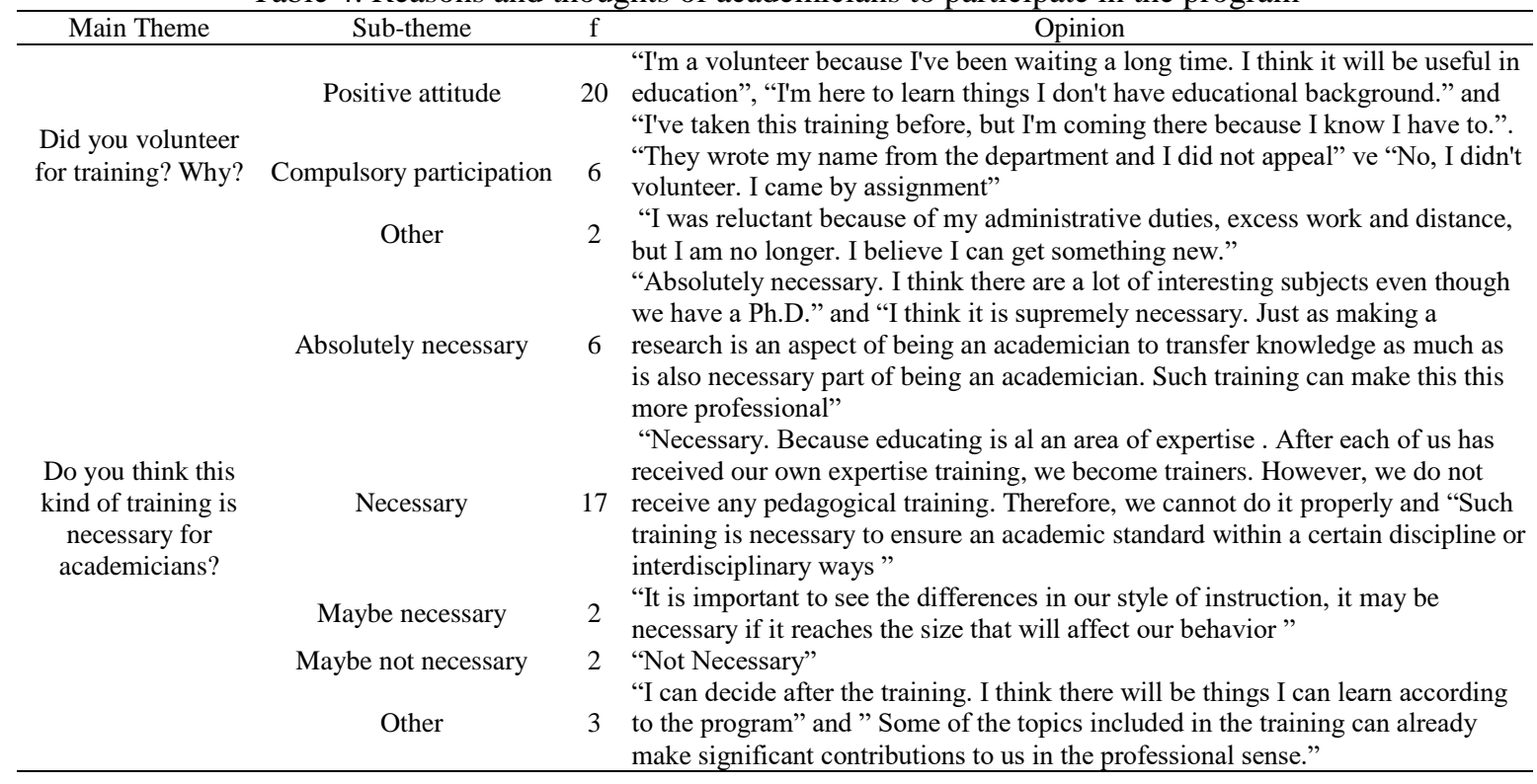

When the achievements of academicians from the program is investigated as given Table 5, it is seen that positive remarks are outweighted. Most of the positive remarks are related to general pedagogical knowledge (Teaching Methods and Techniques $=10$; Assesment and Evaluation $=9$ summing up 19 remarks). The second category consists from good remarks that are neither comments on particular benefits nor some conceptual concludings. The third category is related to other category (Awareness of Own Pedagogical Mistakes $=5$; Self-Development $=3$; Repetition: 3 summing up 11 remarks).

There are also negative comments regarding the program. The first one is related to the subject of the program indicating that content of the program which is very important that participants needs pedagogical content knowledge $(n=11)$. The second one is related to the knowledge of educational contexts of the trainers which are mostly about time management and planning skills $(n=8)$. The third one is related to tools and equipment which belongs to pedagogical knowledge of the trainers $(n=2)$. 
Table 5. Achievements of academicians from the program

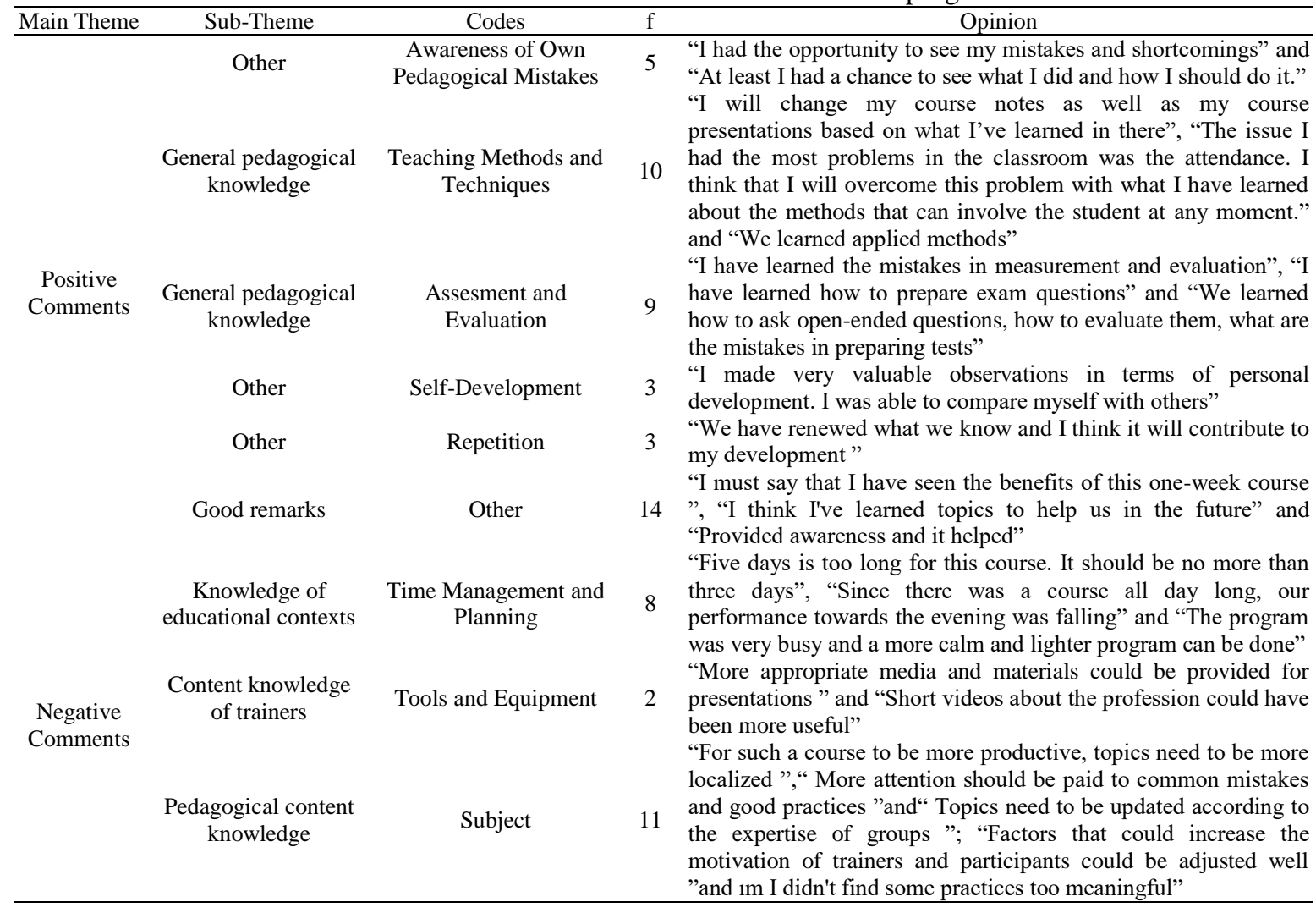

As it is seen in Table 6, the same questions were asked to the participants at the beginning and end of the course and significant differences occurred in the answers received. It was observed that the evaluation expected especially from education showed a high level of variation after the training. This also confirms the importance of the necessity of this kind of education by providing the common values and experiences with academicians in the same faculty through education. Therefore program have contributed positively to updating their knowledge. When the chi-square test was performed for the analysis of the data in Table 6 the first finding given as 10 cells $(0,0 \%)$ have expected count less than 51 indicates that we can use the analysis for chi-square test for the findings regarding yes and no answers. Therefore our asymptotic Significance (2-sided) for Pearson Chi-Square indicates that there is a dramatic change regarding the effectiveness of the program as given in Table 7.

Table 6. Questions asked at the beginning and end of the course and the opinions of the participants

\begin{tabular}{|c|c|c|c|c|c|}
\hline & Question & & & & \\
\hline \multirow{2}{*}{1} & \multirow{2}{*}{ Did you volunteer for the course? } & Yes & 18 & Yes & 44 \\
\hline & & No & 32 & No & 6 \\
\hline \multirow{2}{*}{2} & \multirow{2}{*}{ Do you think the course is necessary? } & Yes & 23 & Yes & 45 \\
\hline & & No & 27 & No & 5 \\
\hline \multirow{2}{*}{3} & \multirow{2}{*}{ Do you think academics need a course with this content? } & Yes & 21 & Yes & 45 \\
\hline & & No & 29 & No & 5 \\
\hline \multirow{2}{*}{4} & \multirow{2}{*}{ Would you have attended the course without the assignment? } & Yes & 9 & Yes & 34 \\
\hline & & No & 41 & No & 16 \\
\hline
\end{tabular}

Table 7. Chi-square tests for yes-no answers

\begin{tabular}{cccc}
\hline Chi-Square Tests & Value & df & Asymptotic Significance (2-sided) \\
\hline Pearson Chi-Square & $16.331^{\mathrm{a}}$ & 3 & .001 \\
Likelihood Ratio & 16.153 & 3 & .001 \\
Linear-by-Linear Association & 7.219 & 1 & .007 \\
N of Valid Cases & 400 & & \\
\hline a. 0 cells $(0.0 \%)$ have expected count less than 5. The minimum expected count is 40.25.
\end{tabular}


Some positive remarks of the academicians can be given as follows:

Participant 1 remarked that "I came here because it was an assignment. I was also angry with those who had appointed me because it coincided with a busy period. After arriving, it was like a therapy. We updated some of our information, some remembered After the first day I tried to continue to the maximum degree. Thank you for such training". This comments indicate that such orientation programs not only have a educational effects but also therapeutic effects as well.

Participant 2 pointed out that "it would be better if there were direct useful applications for my field. However, it was quite helpful and useful. I came reluctantly about how a week will pass. But here I saw it was not. The time went well and we were not bored. The instructors were well prepared". This comments emphasize the significance of pedagogical content knowledge for such programs.

Participant 3 remarked that "First of all, we are very pleased with all our teachers. Each of our professors, who are competent in their fields, sometimes refreshed our knowledge and sometimes expanded our horizons with a different perspective. I thank them all individually". This comments emphasize the interdisciplinary contributions of such an in-service programs.

As it can be seen from the participant opinions reflected as an example, the trainings were very successful. Despite all positive opinions, there were also negative opinions and criticisms. These are briefly as follows. For example, participant 4 indicated that "As we had exams, I couldn't attend some practical classes. I'm sorry I missed those classes. Training is better if they are not put into exam times". This is important remark regarding the planning of such educational formations.

Participant 5 said that "I am very angry that my work is very busy and you have to come here a thousand full-time for a week between the dates that I have made my plans to concentrate fully on individual work. This training didn't do me any good." Therefore, this comments indicates the significance of voluntary partipation for in-service trainings.

Participant 6 said that "Although some of the lessons worked for me, the majority were not related to my field. I have learned about general rules and communication with students, but I haven't been able to learn specifically about the methods I can apply in my field." This comments also emphasize the significance of pedagogical content knowledge for such programs. Therefore both negative and positive comments focus on the the significance of pedagogical content knowledge for such programs.

Participant 7 said that "The timing can be adjusted better. Education can be done in faculties and evenings. It's hard to be here all day." This is also an important remark regarding the planning of such educational formations.

\subsection{Discussion}

When the expectations of the academicians regarding the pedagogical skills was investigated it could be seen that most of them strongly emphasized they had expected to improve their general pedagogical knowledge $(n=18)$, they also strongly indicated that they felt insufficient in that type of knowledge $(n=12)$ and they expressed that they could improve their general pedagogical knowledge after they received the pedagogical formation $(n=19)$. Another dimension that was remarked is knowledge of educational contexts which is also expressed as insufficient $(n=5)$ and was pointed out as improved $(n=8)$ after taking the program. Altough it is very small number, some participant also indicated that they were expected to improve themselves $(n=3)$ and this can be achieved also by the program also $(n=3)$. Another very significant finding of this program is that participants strongly emphasized that pedagogical content knowledge. Both negative and positive comments focus on the the significance of pedagogical content knowledge for such programs implying that in addition to focusing on general pedagogical knowledge, differantiated educational formation programs for different fields should be given based on the expertise of the academicians in order to improve their pedagogical content knowledge.

Final results of this program are about its effectiveness. The asymptotic Significance (2-sided) for Pearson Chi-Square given in Table 7 indicates of the yes/no answers indicate that there is a dramatic change regarding the effectiveness of the program. When the question as "Did you volunteer for the course?" was asked to academicians, it can be seen that there is a dramatic increase in "Yes" and dramatic decrease in "No" answer indicating that academicians were positively affected by the program. When the question as "Do you think the course is necessary?" was asked to academicians, it can be seen that there is a dramatic increase in "Yes" and dramatic decrease in "No" answer indicating that academicians were convinced the necessity of such a program. When the question as "Do you think academics need a course with this content?" was asked to academicians, it can be seen that there is a dramatic increase in "Yes" and dramatic decrease in "No" answer indicating that academicians were satisfied the general content of this program. When the question as "Would you have attended the course without the assignment?" was asked to academicians, it can be seen that there is a dramatic increase in "Yes" and dramatic decrease in "No" answer indicating that academicians' attitude was positively changed as given in Figure 1. 


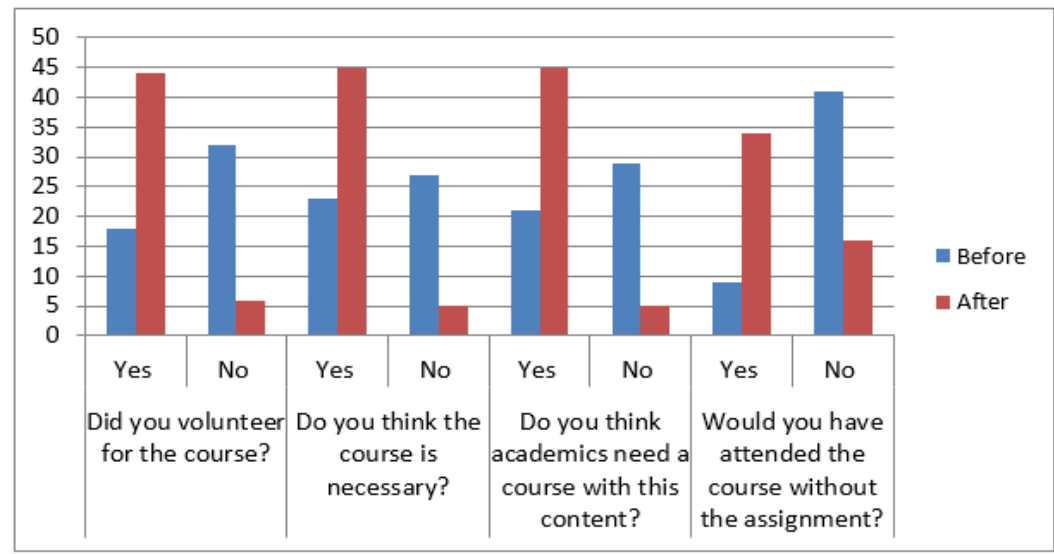

Figure 1. Opinions of the participants before and after the program

As shown in Figure 1, opinions of the participants before and after the program aresupported by the findings of chi-square test given in Table 7. "The idea of Action Research is to identify and investigate educational problems and issues in the best way at the level of classroom and school where there is action. By including research, findings can be applied immediately and problems can be solved more quickly. Therefore, it is important to add what the comments of the participants such an educational program. After one week of intensive training, the same people were asked about their gains from the training. It is seen that it meets the needs of academicians. The most inadequate dimensions as" teaching methods and techniques iwere found to be mostly met by the academicians. For example, participant 8 remarked that "The issue I had the most problems with in the classroom was attendance. I think I will overcome this problem with the techniques I have learned about that will involve the students into the courses". "Assesment and evaluation, awareness of own-mistakes, self-improvement, repetition and other contributions" can also be considered that the program positvely affects their pedagogical knowledge. In general, it is understood that education has a positive effect on expectations. However, it should be noted that a small group is not satisfied with the "timing and planning eğitim of education". For example, participant 9 remarked that "Since it was a course all day, our performance was falling towards the evening". Partipants also suggested that "frequent pedagogical mistakes and good practices should be emphasized more" and pedagogical content knowledge should be more focused than the general pedagogical knowledge. In the same way, this training has a positive effect on the expected performance.

\section{CONCLUSION}

The training of academicians is one of the neglected fields except the training given to other formal teacher candidates. There is no formal study on this. Only pedagogical training workshops are organized annually for some of the academicians through the initiatives of the universities themselves. For a university instructor, there is no clear separation between general pedagogical knowledge with pedagogical content knowledge. Therefore, pedagogical formation courses are important for academicians who have started to give lectures as academicians after receiving education in many different disciplines and have difficulty in applying some basic teaching skills and principles since there is no formation training related to be an instructor.

Today, inadequate pedagogical back-ground can be regarded as the main problem that arise in the teaching activities of the academic staff in Turkey. In particular, it is not expected that an education which ignores the psychological and sociological characteristics of student recognition will be successful. As a result of this, problems in the classroom and the institution are manifested. Classroom management establishing pedagogical relations with the students are among the common problems that academicians have faced. The most important reason for this is the absence of pedagogical formation before starting the profession. In this study, the academicians themselves showed this clearly in their answers to the questions before the training. In particular, this occurs in self-expression, assessment, and communication process.

This study and other studies clearly show that academics have problems in pedagogical backgrounds. Although one week of training seems to be effective, it is limited in terms of sustainability and access to other academicians. Therefore, it is very important to provide workshops, seminars and courses for pedagogical formation courses. On the basis of the experience of the lecturers participating in the course,

Training of trainers: An action-based research for improving the pedagogical skills ... (Bayram Özer) 
suggestions are given as follows: 1) In service programs such as training of trainers should be organized at regular intervals; 2) Educational environments, tools and equipment should be improved; 3) When creating or organizing new educational environments, educators and subject matter experts should be consulted about the educational subject; 4) Class sizes should be reduced for such in-service formation programs; 5) Such an in-service program should focus on pedagogical content knowledge rather than general pedagogical knowledge.

\section{REFERENCES}

[1] Loughran J., Berry A., and Mulhall P., "Pedagogical Content Knowledge,” In: Loughran J., Berry A., Mulhall P. (eds), "Understanding and Developing Science Teachers' Pedagogical Content Knowledge," Professional Learning, vol. 12, Sense Publishers, Rotterdam, 2012.

[2] Cochran, F. K., "Pedagogical Content Knowledge: Teachers' Integration of Subject Matter, Pedagogy, Students, and Learning Environments," Research Matters - to the Science Teacher, NARST, No. 9702, 1997.

[3] Shulman, L. S., "Those who understand: Knowledge growth in teaching," Educational Researcher, vol. 15, no. 2, pp. 4-14. 1986.

[4] Shulman, L., "Knowledge and teaching: Foundations of the new reform," Harvard Educational Review, vol. 57, no. 1 , pp. 1-2, 1987.

[5] Asma, M., Investigation of the effects of a volleyball content knowledge workshop on middle school physical education teachers' pedagogical content knowledge and student learning, Unpublished Doctoral Dissertation. [Online]. Available: https://tez.yok.gov.tr

[6] Musal, B., Abacıoğlu, H., Dicle, O., Akalın, E., Sarığlu, S., and Esen, A. "Faculty development programs in Dokuz Eylül School of Medicine: Intheprocess of curriculum change from traditional to PBL," Medical Education Online [serialonline], vol. 7, no. 2, pp.1-5, 2002.

[7] Gess-Newsome, J., "Pedagogical content knowledge: An introduction and orientation," J. Gess-Newsome \& N. G. Lederman (Haz.), "Examining pedagogical content knowledge: The construct and its implications for science education (s. 3- 17)," The Netherlands: Kluwer Academic Publishers, 2001.

[8] Sullivan, R., Gaffikin, L. and Lowry, E. Tıp eğitimcileri için program geliştirme rehberi, (Çeviren: N. N. Şahin; Çeviri Editörü: Ş.B. Özvarış). JHPIEGO, Hacettepe Halk Sağlığı Vakfı, Ankara, 1999.

[9] Harden, R.M. and Crosby, J. "AME education guide no. 20: The good teacher is more than a lecturer - the tsvelve roles of the teacher," Medical Teacher, vol. 22, no. 4, pp. 334-347, 2000.

[10] MEB, "Öğretmenlik Mesleği Genelyeterlikleri ," 2006. [Online]. Available: https://oygm.meb.gov.tr/ meb_iys_dosyalar/2017_12/13161921_YYretmenlik_MesleYi_Genel_YETERLYKLERi_onaylanan.pdf

[11] Öztürk, Y., Öğretim Elemanlarının Ders Vermelerinin Değerlendirilmesinin Kamu Üniversitelerinde Uygulanabilirliği, Mill i Eğitim: Egitim-Sanat-Kültür. Sayı 141, 1999.

[12] Musal, B., Eğitici Gelişim Programları. Dokuz Eylül Üniversitesi Tıp Fakültesi Dergisi, 2001. 1(Aktif Eğitim Özel Say1s1): 39-47, 2001.

[13] Yolsal, N., Bahadır, G., Karabey, S., Ortaylı, N., Aydın, Z. and Bulut, A, "Development of training of trainers programme sand evaluation of their effectiveness in Istanbul," MedicalTeacher, vol. 25, no. 3, pp. 319-324, 2003.

[14] Özyurda, F., Dökmeci, F., Palaoğlu, Ö. and Arda, B., "The role of interactive training skill scourse in medical education at the Ankara University School of Medicine," Teachingand Learning in Medicine, vol. 14, no. 3, pp. 189-93, 2002.

[15] Çiçeklioğlu, M., Ege Üniversitesi Tıp Fakültesi'nde Yürütülen Eğitici Eğitimi Programının Değerlendirilmesi, Sosyal Bilimler Enstitüsü Eğitim Programları ve Öğretim Anabilim Dalı Yayınlanmamış Yüksek Lisans Tezi, 2004.

[16] Gelen, İ. And Özer, B. "Öğretmenlik Mesleği Genel Yeterliklerine Sahip Olma Düzeyleri Hakkında Öğretmen Adayları Ve Öğretmenlerin Görüşlerinin Değerlendirilmesi," Mustafa Kemal Üniversitesi Sosyal Bilimler Enstitüsü Dergisi, vol. 5, no. 9, pp. 39-55, 2008.

[17] Belm, D., "Establishing Teacher Competencies in Early Care and Education: A Review of Current Models and Options for California, Institute of Industrial Relations," University of California at Berkeley, 2008.

[18] Gordon, T. Etkili Öğretmenlik Ĕgitimi, Çev: Aksay, Ankara, Sistem Yayıncılık, 1996.

[19] Karataş, K. Ardıç, T., and Oral, B. "Öğretmenlik Mesleğinin Yeterlikleri Ve Geleceği: Metaforik Bir Analiz," International Periodical for the Languages, Literature and History of Turkish or Turkic, vol. 12, no. 33, pp. 291-312, 2017.

[20] Demirel, Ö., Öğretme sanatı, Ankara: PegemA Yayınevi, 2006.

[21] Köksal, N., "Öğretmenlik Mesleği Genel Yeterliklerinin Öğretmen, Müdür ve Bakanlık Yetkilileri Tarafından Değerlendirilmesi,” Pamukkale Üniversitesi Eğitim Fakültesi Dergisi Yıl, vol. 1, no. 23, pp. 36-46, 2008.

[22] Ergün, M., Üniversitelerde Öğretim Etkinliğinin Geliştirilmesi. 2000 Yllında Türk Milli Eğitim Örgütü ve Yönetimi Ulusal Sempozyumu. 11-13 Ocak 2001, Ankara: Öğretmen Hüseyin Hüsnü Tekış1k Vakfi Yay: 188-92, 2001.

[23] Alican, İ., Arzık, A., Çalı, Ş., Emerk, K., Ergun, T. ve ark., Marmara Üniversitesi Tıp Fakültesi Ĕgiticilerin Eğitimi Programı. II. Ulusal Tıp Eğitimi Kongresi, İzmir: Ege Üniversitesi Güçlendirme Vakfi Basımevi: 120, 2001.

[24] Özvarış, Ş. B., Aslan, D., Şahin Hodoğlugil, N., and Sayek, İ. A., "Faculty Development Program Evaluation: From Needs Assessment to Long-Term Effects of the Teaching Skills Improvement Program," Teachingand Learning in Medicine, vol. 16, no. 4, pp. 368-75, 2004. 
[25] Rawlinson, D. ve Little, M. "Improving Student Learning Through Classroom Action Research," Florida Department of Education, pp. 11-14, 2004.

[26] Duraiz, L. Eğitimde Kalit e Arayışları 4. Ulusal Kalit e Kongresi: Toplam Kalit e Yönetimi ve Eğitimde Kalite. Kasım. İstanbul, 1995.

[27] Büyüköztürk, Ş., Kılıç Çakmak, E., Akgün, Ö.E., Karadeniz, Ş., and Demirel, F. Bilimsel araştırma yöntemleri. (5. bs), Ankara: Pegem Yayınları, 2010.

[28] Yıldırım, A. and Şimşek. H. Sosyal Bilimlerde Nitel Araştırma (Genişletilmiş 7. Baskı), Ankara: Seçkin Yayıncilık, 2008.

[29] Costello, P.J.M., Action research, Continuum Books: London, 2007.

[30] Cole, F. L. "Content Analysis: Process and Application,” Clinical Nurse Specialist, vol. 2, no. 1, pp. 53-57, 1988. 